\title{
Thioprofundum hispidum sp. nov., an obligately chemolithoautotrophic sulfur-oxidizing gammaproteobacterium isolated from the hydrothermal field on Suiyo Seamount, and proposal of Thioalkalispiraceae fam. nov. in the order Chromatiales
}

Correspondence

Koji Mori mori-koji@nite.go.jp
Koji Mori, ${ }^{1,2}$ Ken-ichiro Suzuki, ${ }^{1}$ Tetsuro Urabe, ${ }^{3}$ Maki Sugihara, ${ }^{2}$ Kenji Tanaka, ${ }^{1}$ Moriyuki Hamada ${ }^{1}$ and Satoshi Hanada ${ }^{2}$

\footnotetext{
${ }^{1}$ Biological Resource Center (NBRC), National Institute of Technology and Evaluation (NITE), 2-5-8 Kazusakamatari, Kisarazu, Chiba 292-0818, Japan

${ }^{2}$ Institute for Biological Resources and Functions, National Institute of Advanced Industrial Science and Technology (AIST), Tsukuba Central 6, 1-1-1 Higashi, Tsukuba, Ibaraki 305-8566, Japan

${ }^{3}$ Department of Earth and Planetary Science, University of Tokyo, Bunkyo-ku, Tokyo 113-0033, Japan
}

\begin{abstract}
A novel mesophilic, facultatively anaerobic, sulfur-oxidizing bacterial strain, designated $\operatorname{gps} 61^{\top}$, was isolated from a surface rock sample collected from the hydrothermal field of Suiyo Seamount on the Izu-Bonin Arc in the Western Pacific Ocean. Cells of the isolate were rod-shaped with a single sheathed polar flagellum. Neither extensive internal membranes nor storage materials were present in the cells. In a $20 \% \mathrm{CO}_{2}$ atmosphere, strain gps $61^{\top}$ grew using thiosulfate, sulfur or tetrathionate as electron donors and oxygen or nitrate as electron acceptors. Other substrates, including organic acids and sugars, did not support growth, indicating that strain gps $61^{\top}$ was an obligate chemolithoautotroph. 16S rRNA gene sequence analysis revealed that strain gps $61^{\top}$ was closely related to Thioprofundum lithotrophicum $106^{\top}$ (98.5\% sequence similarity) in the order Chromatiales. Phylogenetic trees grouped strain gps $61^{\top}$ and Thioprofundum lithotrophicum in the same cluster along with Thioalkalispira microaerophila and Thiohalophilus thiocyanoxidans, but it was apparent from the analysis that the novel strain had definitely departed from the family lineage. On the basis of its phylogenetic position along with its morphological and physiological characteristics, strain gps61 $1^{\top}\left(=\right.$ NBRC $\left.101261^{\top}=\mathrm{DSM} 18546^{\top}\right)$ represents a novel species of the genus Thioprofundum, for which the name Thioprofundum hispidum sp. nov. is proposed. In addition, we propose a novel family name, Thioalkalispiraceae, in the order Chromatiales, to accommodate the genera Thioalkalispira, Thiohalophilus and Thioprofundum.
\end{abstract}

Hydrothermal vents have been discovered worldwide and host peculiar ecosystems that include chemolithoautotrophs as primary producers. Culture-independent analyses, based on 16S rRNA gene sequences, have revealed that various micro-organisms inhabit such environments (Corre et al., 2001; Marteinsson et al., 1995; Takai \& Horikoshi, 1999; Takai et al., 2001, 2003). To date, novel chemolithoautotrophic sulfur-oxidizing bacteria belonging to the phyla

The GenBank/EMBL/DDBJ accession number for the 16S rRNA gene sequence of strain $\mathrm{gps} 61^{\top}$ is $\mathrm{AB} 266389$.

Two supplementary figures are available with the online version of this paper.
Aquificae and Proteobacteria have been found in hydrothermal vent systems. The class Gammaproteobacteria contains many environmental strains derived from symbiotic bacteria associated with invertebrates living in hydrothermal vents and cold-seep systems. Such symbionts are considered to be sulfur- or methane-oxidizing bacteria that supply energy to their host invertebrates (Cavanaugh et al., 1981; Di Meo et al., 2000; Distel et al., 1994; Felbeck, 1981; Feldman et al., 1997). In addition, several environmental strains belonging to the class Gammaproteobacteria have been retrieved from hydrothermal fields, cold-seep sediments and marine crusts (Arakawa et al., 2006; Inagaki et al., 2004; Li et al., 1999; Santelli et al., 2008), some of which have been 
suggested as having sulfur-oxidizing metabolism (Hirayama et al., 2007; Sunamura et al., 2004). As for cultivated Gammaproteobacteria, some species of the genera Halothiobacillus and Thiomicrospira have been isolated from these environments (Brinkhoff et al., 1999; Sievert et al., 2000; Takai et al., 2004).

Some previously uncharacterized bacterial strains from culture-independent analyses have been identified as possible sulfur-oxidizers belonging to the order Chromatiales of the class Gammaproteobacteria. At the time of writing, the order Chromatiales included three families, namely, Chromatiaceae, Ectothiorhodospiraceae and Halothiobacillaceae. Almost all members of these families are known to oxidize sulfur compounds, although there are some exceptions. Species belonging to the families Chromatiaceae and Ectothiorhodospiraceae are mainly anoxygenic photolithoautotrophic bacteria, which are able to oxidize sulfur compounds under anaerobic conditions by using light (Imhoff, 2005a, b). On the other hand, the family Halothiobacillaceae contains non-photosynthetic, chemolithoautotrophic, sulfur-oxidizing bacteria isolated from hypersaline, marine and terrestrial environments containing hydrothermal vent systems; its members can oxidize sulfur compounds under aerobic conditions (Durand et al., 1993; Ito et al., 2005; Mori \& Suzuki, 2008; Sievert et al., 2000). In this study, a group of previously uncharacterized bacterial strains found in hydrothermal fields and cold-seep sediments were found to be phylogenetically distant from the above families but formed a distinct clade within the order Chromatiales. This suggested that the creation of a new family was necessary to encompass these strains. To our knowledge, no such taxon has previously been proposed despite the fact that these isolates are clearly separate from recognized families (Sorokin et al., 2007; Takai et al., 2009). This is likely to be because of the highly complex nature of higher taxa in the class Gammaproteobacteria.

In this study, an obligately chemolithoautotrophic, sulfuroxidizing bacterium, designated strain gps $61^{\mathrm{T}}$, was isolated from a rock sample collected from the hydrothermal field on Suiyo Seamount. Based on 16S rRNA gene sequence analysis, the isolate belonged to the genus Thioprofundum of the order Chromatiales. Data from phylogenetic and phenotypic analyses suggested that strain gps $61^{\mathrm{T}}$ warrants classification as a novel species. On the basis of our phylogenetic analysis, it is also proposed that a new family be created to encompass the novel strain and its closest relatives.

Strain gps $61^{\mathrm{T}}$ was isolated from Suiyo Seamount, located in the Izu-Bonin Arc in the Western Pacific Ocean (28 $34^{\prime}$ $\mathrm{N} 140^{\circ} 39^{\prime}$ E). The region has a submarine caldera with numerous hydrothermal vents at a depth of $1390 \mathrm{~m}$ (Glasby et al., 2000). Rock samples were collected from the site, from July 19-23, 2002, using the benthic multicoring system (BMS; Metal Mining Agency of Japan), a tethered marine rock drill, to obtain cores from under the seafloor. The rock core samples were collected near the black smoker hydrothermal vents $\left(\sim 300{ }^{\circ} \mathrm{C}\right)$. For microbial cultivation, surface layers of the rock core were selected, crushed immediately with a vice in an anaerobic chamber (COY Laboratory Products) and resuspended in basal medium under an $\mathrm{N}_{2} / \mathrm{CO}_{2}(4: 1, \mathrm{v} / \mathrm{v})$ atmosphere. The basal medium was composed of $\left(\mathrm{l}^{-1}\right) 0.60 \mathrm{~g} \mathrm{KH}_{2} \mathrm{PO}_{4}$, $0.11 \mathrm{~g} \mathrm{~K}_{2} \mathrm{HPO}_{4}, 3.05 \mathrm{~g} \mathrm{MgCl}_{2} \cdot 6 \mathrm{H}_{2} \mathrm{O}, 0.15 \mathrm{~g} \mathrm{CaCl}_{2} \cdot 2 \mathrm{H}_{2} \mathrm{O}$,

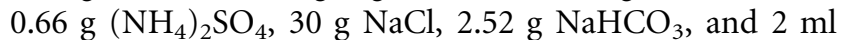
each of trace element and vitamin solutions of NBRC medium 377 (NBRC, 2010). For the enrichment of sulfuroxidizing micro-organisms, AP8SO1 medium, comprising basal medium supplemented with $5 \mathrm{mM} \mathrm{Na} \mathrm{S}_{2} \mathrm{O}_{3}$, was used under an atmosphere of $\mathrm{N}_{2} / \mathrm{CO}_{2} / \mathrm{O}_{2}(75: 20: 5, \mathrm{v} / \mathrm{v} / \mathrm{v}$; $150 \mathrm{kPa}$ ) in a vial sealed with a butyl rubber stopper and an aluminium cap; the enrichment was performed at $50{ }^{\circ} \mathrm{C}$. After incubation for 1 week, thiosulfate was partly converted into elemental sulfur in the enrichment culture. The presence of elemental sulfur was determined during each transfer to fresh AP8SO1 medium and rod-shaped micro-organisms were observed in the culture using a light microscope (Olympus model AX70). These phenomena suggested that the small, but significant, production of elemental sulfur was due to biotic oxidation of thiosulfate by the rod-shaped micro-organisms present in the vials. Sulfur precipitation was observed in an enrichment culture incubated at $37{ }^{\circ} \mathrm{C}$ using AP8SO1 medium supplemented with $20 \mathrm{mM} \mathrm{Na}_{2} \mathrm{~S}_{2} \mathrm{O}_{3}$ (AP8SO2) under an atmosphere of $\mathrm{N}_{2} / \mathrm{CO}_{2} / \mathrm{O}_{2}(60: 20: 20,150 \mathrm{kPa})$. These culture conditions were used for the isolation of the thiosulfate-oxidizer by serial dilution. After multiple dilutions, incubation and transfer of the culture, a micro-organism exhibiting oxidation of sulfur compounds was successfully isolated as a pure culture and was designated strain gps $61^{\mathrm{T}}$. The purity of the isolate was verified by microscopic observation, inoculation into media containing various heterotrophic substrates and determination of the 16S rRNA gene sequence, which was amplified using various primer sets (Mori \& Suzuki, 2008).

Cells of strain gps $61^{\mathrm{T}}$ were rod-shaped, $\sim 0.3 \times 1.5-2.0 \mu \mathrm{m}$, and had single sheathed polar flagella (Fig. 1); however, motility was not observed under any growth conditions tested. Observation using electron microscopy revealed that the cells had neither storage compounds nor extensive internal membranes. Gram-staining was negative and oxidase and catalase activities (Tamaki et al., 2003) were positive and negative, respectively.

Fatty acid methyl ester analysis was performed using the GC/MS method (Hanada et al., 2002) and the MIDI microbial identification system. The major cellular fatty acids were $\mathrm{C}_{16: 0}(50 \%$ of the total fatty acids) and branched $\mathrm{C}_{17: 0}(29 \%)$. The branched $\mathrm{C}_{17: 0}$ could be distinguished from both the iso- and anteiso-branched fatty acids, although the binding position of the methyl group could not be precisely determined. The strain also contained $\mathrm{C}_{16: 1} \omega 7 c(16 \%), \mathrm{C}_{18: 1} \omega 7 c(6 \%), \mathrm{C}_{15: 0}(5 \%)$ and $\mathrm{C}_{14: 0}(2 \%)$ as minor fatty acid components. The 


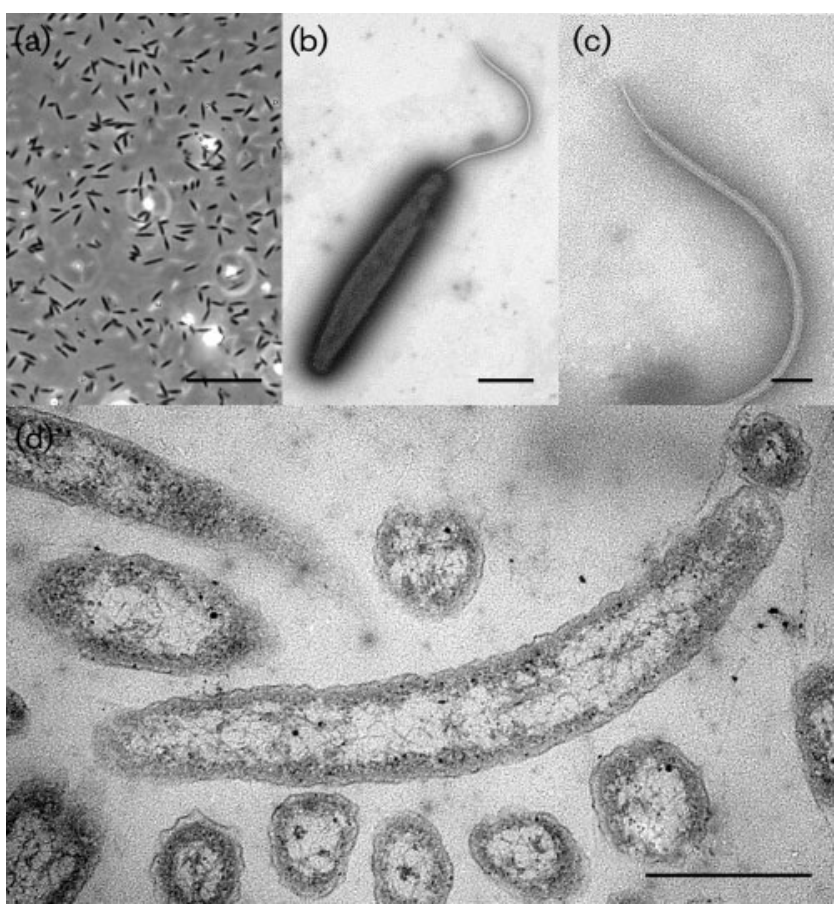

Fig. 1. Cell morphology of strain gps $61^{\top}$. Phase-contrast micrograph (a) and negatively stained cells (b, c) of strain gps $61^{\top}$ and ultrathin section of strain gps $61^{\top}$ observed with a transmission electron microscope (model $\mathrm{H}-7600$; Hitachi) (d). The cells have a single thick polar flagellum ( $20 \mathrm{~nm}$ in diameter) and a concealing core was observed at the tip. Bars, $5 \mu \mathrm{m}(\mathrm{a}), 0.5 \mu \mathrm{m}$ (b, d) and 100 $\mathrm{nm}$ (c).

genomic DNA G + C content (Mori et al., 2000) of strain gps $61^{\mathrm{T}}$ was $62.9 \mathrm{~mol} \%$. An isoprenoid quinone was extracted from the cells according to the protocol outlined by Nakagawa \& Yamasato (1993) and analysed using an LCMS-QP 8000 alpha spectrometer (Shimadzu). The isolate contained menaquinone but we were unable to determine the isoprenoid side chain length due to the low extraction amount.

Utilization of electron acceptors and donors was determined by measuring $\mathrm{OD}_{660}$ (spectrophotometer model $\mathrm{U}$ 2800; Hitachi), thiosulfate and sulfate concentration (HPLC model 2695 with conductivity detector model 432 and IC-Pak Anion column; Waters) (Mori et al., 2008) and cell density via microscopic observation. Strain gps $61^{\mathrm{T}}$ grew using thiosulfate, elemental sulfur and tetrathionate as sole electron donors. However, the following substrates did not support growth (mM): sulfide (2 and 5), $\mathrm{CH}_{4}, \mathrm{H}_{2}$, $\mathrm{H}_{2}+$ acetate (10), methanol (2 and 5), formate (10 and 30), acetate (10 and 30$)$, butyrate (10), citrate (10), fumarate (10), glutamate (10), lactate (10), pyruvate (10), malate (10), succinate (10), L-arginine (10), L-asparagine (10), Lcysteine (10), L-histidine (10), L-leucine (10), L-methionine (10), arabinose (5), fructose (5), galactose (5), glucose (5), inositol (5), mannose (5), raffinose (5), sucrose (5) and xylose (10). The utilization of electron acceptors as a substitute for oxygen was tested by microscopic observation after 1 week of cultivation at $37{ }^{\circ} \mathrm{C}$. Under anaerobic conditions $\left(\mathrm{N}_{2} / \mathrm{CO}_{2}, 80: 20, \mathrm{v} / \mathrm{v} ; 150 \mathrm{kPa}\right)$, strain gps61 ${ }^{\mathrm{T}}$ was able to use nitrate $(10 \mathrm{mM})$ as an electron acceptor in the presence of thiosulfate or elemental sulfur. Nitrite was not detected in the culture on nitrate using a colorimetric assay (Hewitt \& Nicholas, 1964). The following electron acceptors $(\mathrm{mM})$ were not used, even in the presence of thiosulfate or elemental sulfur: nitrite (2.5 and 5), fumarate (10), iron(III) citrate (5) (Heising et al., 1999), manganese (5), selenate (2.5 and 5), selenite (2.5 and 5) and arsenate (2.5 and 5). In the presence of thiosulfate under an atmosphere of $\mathrm{N}_{2} / \mathrm{CO}_{2}(80: 20, \mathrm{v} / \mathrm{v} ; 150 \mathrm{kPa})$, exposure to light from a halogen lamp did not induce growth of strain gps $61^{\mathrm{T}}$; therefore, the isolate was not capable of anoxygenic photosynthesis. Because strain gps $61^{\mathrm{T}}$ was unable to use electron donors other than thiosulfate, elemental sulfur and tetrathionate, strain gps61 $1^{\mathrm{T}}$ was considered to be an obligate chemolithoautotroph that uses sulfur oxidation and carbon dioxide fixation.

Temperature and $\mathrm{pH}$ ranges for growth were determined using a temperature gradient incubator (model TN-2612; ADVANTEC). The $\mathrm{pH}$ of the $\mathrm{AP} 8 \mathrm{SO} 2$ medium was adjusted by the addition of $10 \%(\mathrm{w} / \mathrm{v}) \mathrm{Na}_{2} \mathrm{CO}_{3}$ or $0.2 \mathrm{M}$ $\mathrm{HCl}$. The temperature range for growth of strain gps $61^{\mathrm{T}}$ was $29-43{ }^{\circ} \mathrm{C}$ (optimum $39{ }^{\circ} \mathrm{C}$ ). Although slight growth was observed at $50{ }^{\circ} \mathrm{C}$ during the first enrichment process, microbial activity was not detected at that temperature. The initial $\mathrm{pH}$ range for growth at $37{ }^{\circ} \mathrm{C}$ was $\mathrm{pH}$ 6-8 (optimum $\mathrm{pH}$ 7). The $\mathrm{NaCl}$ concentration for growth ranged from $1-4 \%(\mathrm{w} / \mathrm{v}) \mathrm{NaCl}$ (optimum $2 \%$ ).

Cell density and concentration of thiosulfate and sulfate over time on either thiosulfate or elemental sulfur were determined (Supplementary Fig. S1, available in IJSEM Online). The maximum cell numbers of strain gps $61^{\mathrm{T}}$ grown on thiosulfate and elemental sulfur were almost identical $\left(8.70 \times 10^{6}\right.$ and $7.77 \times 10^{6}$ cells $\mathrm{ml}^{-1}$, respectively). The doubling times on thiosulfate and elemental sulfur were 14.9 and $26.2 \mathrm{~h}$, respectively. Cells grown on thiosulfate converted $13.3 \mathrm{mM}$ thiosulfate into $19.2 \mathrm{mM}$ sulfate and an undetermined amount of elemental sulfur.

The nearly complete sequence of the 16S rRNA gene of strain gps $61^{\mathrm{T}}$ was determined following methods described previously (Hattori et al., 2000). After alignment of sequences using the ARB program (Ludwig et al., 2004), phylogenetic trees were reconstructed using three methods: the neighbour-joining method using the CLUSTAL_X program (Saitou \& Nei, 1987; Thompson et al., 1997), the maximum-likelihood method with the NucML program in the MOLPHY software package (Adachi \& Hasegawa, 1995; Hasegawa et al., 1985; Mori et al., 2003) and the maximum-parsimony method in PAUP version 4 using parameters as described previously (Mori et al., 2003). Environmental clone sequences were used for analysis after screens for chimeras were performed using the Mallard program (Ashelford et al., 2006). The phylogenetic analyses 
indicated that strain gps $61^{\mathrm{T}}$ was a member of the genus Thioprofundum (Takai et al., 2009) in the order Chromatiales in the class Gammaproteobacteria (Fig. 2 and Supplementary Fig. S2). The sequence similarity between strain gps $61^{\mathrm{T}}$ and its closest neighbour, Thioprofundum lithotrophicum, was $98.5 \%$. Furthermore, the isolate was closely related to environmental clone sequences (92.1-95.6\%) and uncharacterized marine denitrifying sulfur-oxidizing isolates found in hydrothermal systems such as strains OAII2 and NDII.1 (96.3\% and 93.6\%, respectively) (Meyer et al., 2007). Thioalkalispira microaerophila and Thiohalophilus thiocyanoxidans were members of the same cluster albeit with somewhat lower similarity to the Thioprofundum strains ( $93-94 \%)$. This cluster was recovered in all phylogenetic trees reconstructed using different analytical methods, despite the fact that the bootstrap score at the node obtained from the neighbour-joining method was not particularly high. The phylogenetic analyses also suggested that the cluster, which included gps61 ${ }^{\mathrm{T}}$, should be separated from the environmental clone cluster that included invertebrate symbionts. The genera Nitrosococcus and Rheinheimera were obviously separated from the families of the order
Chromatiales in our analyses (Supplementary Fig. S2), which suggests the need for reclassification of this group.

Characteristics of strain gps $61^{\mathrm{T}}$ and Thioprofundum lithotrophicum are summarized in Table 1. Thioprofundum lithotrophicum is a moderately thermophilic, piezophilic, sulfur-oxidizing bacterium isolated from a black smoker chimney in the Mid Atlantic Ridge (Takai et al., 2009) whose $16 \mathrm{~S}$ rRNA gene sequence was very similar to that of strain gps6 $1^{\mathrm{T}}$, as were some of its phenotypic features. However, strain gps $61^{\mathrm{T}}$ clearly differed from Thioprofundum lithotrophicum in the following characteristics. Optimum growth of Thioprofundum lithotrophicum was observed at $50{ }^{\circ} \mathrm{C}$, whereas strain gps $61^{\mathrm{T}}$ grew optimally at $39{ }^{\circ} \mathrm{C}$ and could not grow at $50{ }^{\circ} \mathrm{C}$. Strain gps61 $1^{\mathrm{T}}$ was able to grow in the presence of $20 \%$ oxygen, whereas Thioprofundum lithotrophicum was unable to grow at oxygen concentrations $>5 \%$. Thioprofundum lithotrophicum used sulfite as an electron donor, unlike strain gps61 ${ }^{\mathrm{T}}$. The genomic DNA G $+\mathrm{C}$ content differed between strain gps61 ${ }^{\mathrm{T}}(63 \mathrm{~mol} \%)$ and Thioprofundum lithotrophicum (66 mol\%). Furthermore, DNA-DNA hybridization studies (Ezaki et al., 1988, 1989)

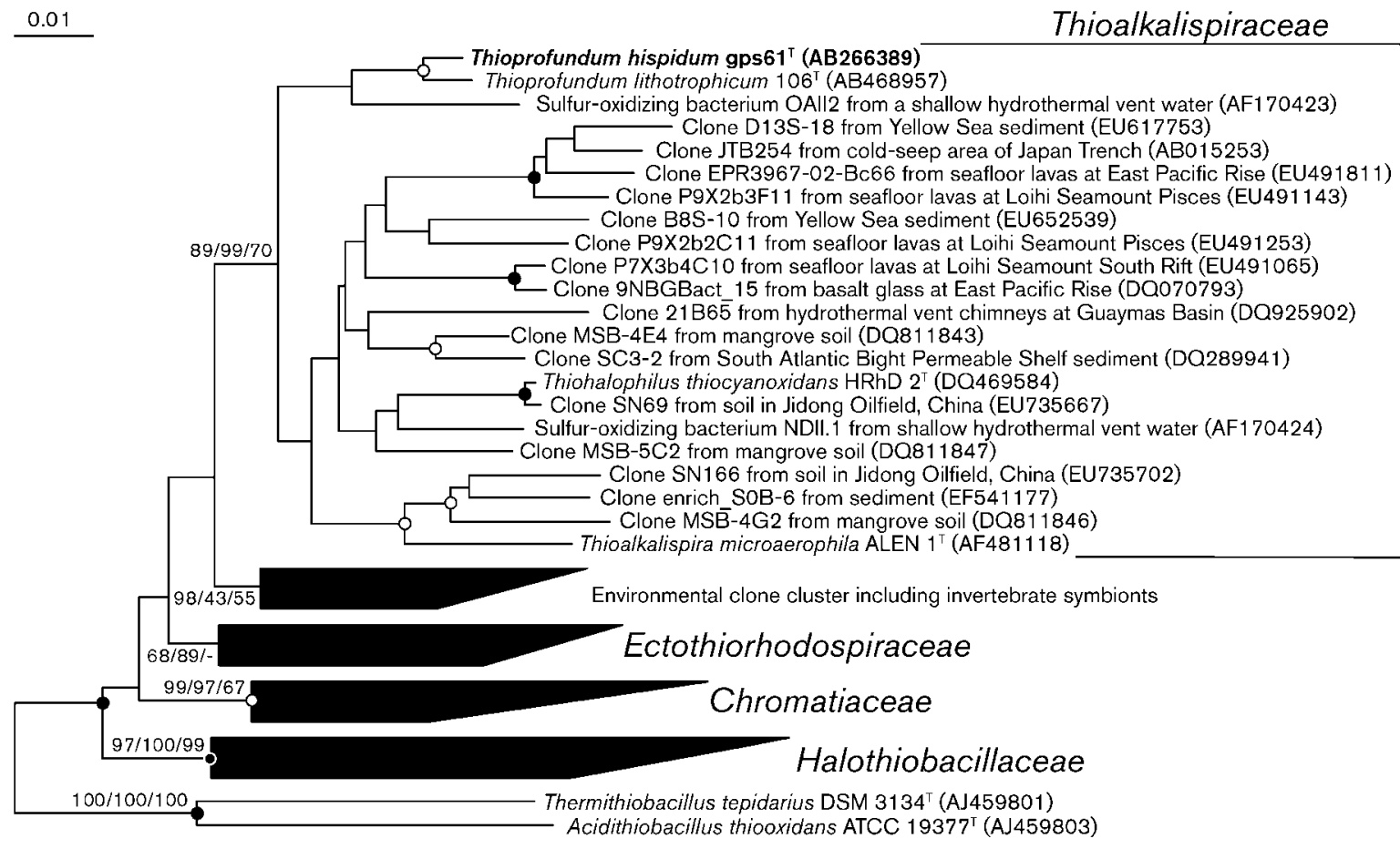

Fig. 2. Phylogenetic tree based on $16 \mathrm{~S}$ rRNA gene sequences of strain gps $61^{\top}$, type species in the orders Chromatiales (excluding members of the genera Nitrosococcus and Rheinheimera) and Acidithiobacillales and uncharacterized environmental clones, inferred using the neighbour-joining method after alignment with the ARB program. The alignment dataset was extracted using the ARB default filter (gamma_2_rr5_dec4), and 1438 positions were used for reconstructing phylogenetic trees. Reference sequences used for the analysis but not shown in collapsed branches are shown in Supplementary Fig. S2 along with their accession numbers. Bootstrap values of neighbour-joining/maximum-likelihood/ maximum-parsimony trees are indicated at the corresponding nodes. Probability scores at branching points obtained with three analysis methods are indicated by solid circles ( $>95 \%$ by all methods) and open circles ( $>90 \%$ by two methods). Bar, 0.01 substitutions per nucleotide position. 
Table 1. Characteristics of strain gps $61^{\top}$, Thioprofundum lithotrophicum, Thioalkalispira microaerophila and Thiohalophilus thiocyanoxidans

Taxa: 1 , gps $61^{\mathrm{T}} ; 2$, Thioprofundum lithotrophicum $106^{\mathrm{T}} ; 3$, Thioalkalispira microaerophila ALEN $1^{\mathrm{T}}$; 4 , Thiohalophilus thiocyanoxidans HRhD $2^{\mathrm{T}}$. All strains were chemolithoautotrophic. Reference data are from Sorokin et al. (2002, 2007) and Takai et al. (2009). +, Positive; -, negative; ND, not determined.

\begin{tabular}{|c|c|c|c|c|}
\hline Characteristic & 1 & 2 & 3 & 4 \\
\hline Morphology & Rod & Short or spiral rod & Spiral rod & Rod \\
\hline Intracellular deposit & - & ND & + & ND \\
\hline Requirement for oxygen & $\begin{array}{c}\text { Facultatively anaerobic } \\
\text { and microaerobic }\end{array}$ & Facultatively anaerobic & Microaerobic & $\begin{array}{c}\text { Facultatively } \\
\text { anaerobic }\end{array}$ \\
\hline Photosynthesis & - & ND & - & ND \\
\hline Electron acceptor(s) & $\mathrm{O}_{2}, \mathrm{NO}_{3}{ }^{-}$ & $\mathrm{O}_{2}, \mathrm{NO}_{3}{ }^{-}$ & $\mathrm{O}_{2}$ & $\mathrm{O}_{2}, \mathrm{NO}_{2}{ }^{-}$ \\
\hline Electron donors & $\mathrm{S}^{0}, \mathrm{~S}_{2} \mathrm{O}_{3}{ }^{2-}, \mathrm{S}_{4} \mathrm{O}_{6}{ }^{2-}$ & $\mathrm{S}^{0}, \mathrm{~S}_{2} \mathrm{O}_{3}{ }^{2-}, \mathrm{S}_{4} \mathrm{O}_{6}{ }^{2-}, \mathrm{SO}_{3}{ }^{2-\star}$ & $\mathrm{S}^{2-}, \mathrm{S}_{8}{ }^{2-}, \mathrm{S}^{0}, \mathrm{~S}_{2} \mathrm{O}_{3}{ }^{2-}, \mathrm{S}_{4} \mathrm{O}_{6}{ }^{2-}$ & $\begin{array}{l}\mathrm{S}^{2-}, \mathrm{S}_{2} \mathrm{O}_{3}{ }^{2-} \\
\text { thiocyanate }\end{array}$ \\
\hline Optimum temperature for growth $\left({ }^{\circ} \mathrm{C}\right)$ & 39 & 50 & $30 \dagger$ & $30 \dagger$ \\
\hline Optimum $\mathrm{pH}$ for growth & 7 & 7 & 10 & 7.5 \\
\hline Optimum $\mathrm{NaCl}$ concentration for growth & $2 \%$ & $3 \%$ & $3 \%$ & $9 \%$ \\
\hline DNA $\mathrm{G}+\mathrm{C}$ content $(\mathrm{mol} \%)$ & 62.9 & 66 & 58.9 & 58.2 \\
\hline
\end{tabular}

*Thioprofundum lithotrophicum was not able to use sulfite as an electron donor in our analysis.

$\dagger$ Growth temperature only, not optimum, was reported.

between strain gps61 $1^{\mathrm{T}}$ and Thioprofundum lithotrophicum showed relatedness values of only 11-21\%, strongly suggesting that they should be classified as different species. Based on its phylogenetic position as well as its phenotypic and chemotaxonomic properties, strain gps $61^{\mathrm{T}}$ represents a novel species, for which the name Thioprofundum hispidum sp. nov. is proposed.

Phylogenetic analyses based on 16S rRNA gene sequences revealed that strain gps61 ${ }^{\mathrm{T}}$ and Thioprofundum lithotrophicum could be clearly distinguished from the families Chromatiaceae, Ectothiorhodospiraceae and Halothiobacillaceae of the order Chromatiales in the class Gammaproteobacteria (Fig. 2). Furthermore, this lineage contained Thioalkalispira microaerophila and Thiohalophilus thiocyanoxidans. Sorokin et al. (2002) reported that Thioalkalispira microaerophila is an alkaliphilic sulfur-oxidizing bacterium and the phylogenetic position was deeply branched and obscured in the class Gammaproteobacteria; subsequently, it was tentatively classed as a member of the family Ectothiorhodospiraceae based on the taxonomic outlines of Bergey's Manual of Systematic Bacteriology (http://www.bergeys.org/outlines.html). The phylogenetic position of Thiohalophilus thiocyanoxidans, a halophilic sulfur-oxidizing bacterium, was only indicated as a member of the class Gammaproteobacteria (Sorokin et al., 2007). In our phylogenetic analyses, however, Thioalkalispira microaerophila and Thiohalophilus thiocyanoxidans were part of the same lineage, along with strain gps61 ${ }^{\mathrm{T}}$ and Thioprofundum lithotrophicum. Some phenotypic features of Thioalkalispira microaerophila and Thiohalophilus thiocyanoxidans, such as chemolithoautotrophy, sulfur-oxidation and moderately halophily, were similar to those of strain $\mathrm{gps} \mathrm{1}^{\mathrm{T}}$ and Thioprofundum lithotrophicum (Table 1). Accordingly, we propose the new family name Thioalkalispiraceae fam. nov. in the order Chromatiales to accommodate the genera Thioalkalispira, Thiohalophilus and Thioprofundum. In the order Chromatiales, the phylogenetic distances of members of the novel family and those of the families Chromatiaceae, Ectothiorhodospiraceae and Halothiobacillaceae, based on $16 \mathrm{~S}$ rRNA gene sequences, were $93.1 \%, 92.9 \%$ and $90.2 \%$, respectively.

\section{Description of Thioalkalispiraceae fam. nov.}

Thioalkalispiraceae (Thi.o.al.ka.li.spi.ra'ce.a.e. N.L. fem. n. Thioalkalispira the type genus of family; suff. -aceae ending to denote a family; N.L. fem. pl. n. Thioalkalispiraceae the family of the genus Thioalkalispira).

The cell wall is of the Gram-negative type. Mesophilic or moderately thermophilic. Strictly chemolithoautotrophic. Growth occurs by sulfur oxidation and carbon dioxide fixation. Members of the family are moderately halophilic and are isolated from marine and saline environments. The genomic DNA G $+\mathrm{C}$ content is $59-66 \mathrm{~mol} \%$. The phylogenetic position is in order Chromatiales in class Gammaproteobacteria of phylum Proteobacteria. The type genus of the family is Thioalkalispira.

\section{Description of Thioprofundum hispidum sp. nov.}

Thioprofundum hispidum (his'pi.dum. L. neut. adj. hispidum bristly).

Cells are Gram-reaction-negative, straight, non-motile rods, $\sim 0.3 \times 1.5-2.0 \mu \mathrm{m}$ and have a single thick polar flagellum. Oxidase-positive and catalase-negative. Facultatively anaerobic and obligately chemolithoautotrophic. Grows at 29 and $43{ }^{\circ} \mathrm{C}$ (optimum $39{ }^{\circ} \mathrm{C}$ ). $\mathrm{pH}$ range for 
growth is 6-8 (optimum $\mathrm{pH} 7$ ). The $\mathrm{NaCl}$ concentration for growth ranges from 1 to $4 \%$ (optimum $2 \%$ ). Either oxygen or nitrate is used as an electron acceptor but nitrite, fumarate, iron(III) citrate, manganese, selenate, selenite and arsenate are not. Thiosulfate, elemental sulfur and tetrathionate are used as electron donors. Carbon dioxide is used as a sole carbon source; organic compounds are not used for growth. Major cellular fatty acids are $\mathrm{C}_{16: 0}$ and branched $\mathrm{C}_{17: 0}$. Minor components are $\mathrm{C}_{16: 1} \omega 7 c, \mathrm{C}_{18: 1} \omega 7 c, \mathrm{C}_{15: 0}$ and $\mathrm{C}_{14: 0}$.

The type strain, gps61 $1^{\mathrm{T}}\left(=\right.$ NBRC $101261^{\mathrm{T}}=$ DSM $\left.18546^{\mathrm{T}}\right)$, was isolated from a rock sample collected from the hydrothermal field on Suiyo Seamount, Izu-Bornin Arc, Western Pacific Ocean. The genomic DNA G + C content of the type strain is $62.9 \mathrm{~mol} \%$ (determined by HPLC).

\section{Acknowledgements}

We thank the operation team of BMS and the crew of work boat Dainihakureimaru for collecting samples. We thank Kuniko Shimamura for technical support. The Ministry of Education, Science \& Technology (MEST) of Japan funded part of this research through the Special Coordination Fund 'Archaean Park Project': International Research Project on Interaction Between SubVent Biosphere and Geo-Environments.

\section{References}

Adachi, J. \& Hasegawa, M. (1995). Improved dating of the human/ chimpanzee separation in the mitochondrial DNA tree: heterogeneity among amino acid sites. J Mol Evol 40, 622-628.

Arakawa, S., Sato, T., Sato, R., Zhang, J., Gamo, T., Tsunogai, U., Hirota, A., Yoshida, Y., Usami, R. \& other authors (2006). Molecular phylogenetic and chemical analyses of the microbial mats in deep-sea cold seep sediments at the northeastern Japan Sea. Extremophiles 10, 311-319.

Ashelford, K. E., Chuzhanova, N. A., Fry, J. C., Jones, A. J. \& Weightman, A. J. (2006). New screening software shows that most recent large $16 \mathrm{~S}$ rRNA gene clone libraries contain chimeras. Appl Environ Microbiol 72, 5734-5741.

Brinkhoff, T., Muyzer, G., Wirsen, C. O. \& Kuever, J. (1999), Thiomicrospira chilensis sp. nov., a mesophilic obligately chemolithoautotrophic sulfur-oxidizing bacterium isolated from a Thioploca mat. Int J Syst Bacteriol 49, 875-879.

Cavanaugh, C. M., Gardiner, S. L., Jones, M. L., Jannasch, H. W. \& Waterbury, J. B. (1981). Prokaryotic cells in the hydrothermal vent tube worm Riftia pachyptila Jones: possible chemoautotrophic symbionts. Science 213, 340-342.

Corre, E., Reysenbach, A. L. \& Prieur, D. (2001). $\varepsilon$-Proteobacterial diversity from a deep-sea hydrothermal vent on the Mid-Atlantic Ridge. FEMS Microbiol Lett 205, 329-335.

Di Meo, C. A., Wilbur, A. E., Holben, W. E., Feldman, R. A., Vrijenhoek, R. C. \& Cary, S. C. (2000). Genetic variation among endosymbionts of widely distributed vestimentiferan tubeworms. Appl Environ Microbiol 66, 651-658.

Distel, D., Felbeck, H. \& Cavanaugh, C. (1994). Evidence for phylogenetic congruence among sulfur-oxidizing chemoautotrophic bacterial endosymbionts and their bivalve hosts. J Mol Evol 38, 533542.
Durand, P., Reysenbach, A.-L., Prieur, D. \& Pace, N. (1993). Isolation and characterization of Thiobacillus hydrothermalis sp. nov., a mesophilic obligately chemolithotrophic bacterium isolated from a deep-sea hydrothermal vent in Fiji Basin. Arch Microbiol 159, 39-44.

Ezaki, T., Hashimoto, Y., Takeuchi, N., Yamamoto, H., Liu, S. L., Miura, H., Matsui, K. \& Yabuuchi, E. (1988). Simple genetic method to identify viridans group streptococci by colorimetric dot hybridization and fluorometric hybridization in microdilution wells. J Clin Microbiol 26, 1708-1713.

Ezaki, T., Hashimoto, Y. \& Yabuuchi, E. (1989). Fluorometric deoxyribonucleic acid-deoxyribonucleic acid hybridization in microdilution wells as an alternative to membrane filter hybridization in which radioisotopes are used to determine genetic relatedness among bacterial strains. Int J Syst Bacteriol 39, 224-229.

Felbeck, H. (1981). Chemoautotrophic potential of the hydrothermal vent tube worm, Riftia pachyptila Jones (Vestimentifera). Science 213, 336-338.

Feldman, R. A., Black, M. B., Cary, C. S., Lutz, R. A. \& Vrijenhoek, R. C. (1997). Molecular phylogenetics of bacterial endosymbionts and their vestimentiferan hosts. Mol Mar Biol Biotechnol 6, 268-277.

Glasby, G. P., lizasa, K., Yuasa, M. \& Usui, A. (2000). Submarine hydrothermal mineralization on the Izu-Bonin Arc, south of Japan: an overview. Mar Georesour Geotechnol 18, 141-176.

Hanada, S., Takaichi, S., Matsuura, K. \& Nakamura, K. (2002). Roseiflexus castenholzii gen. nov., sp. nov., a thermophilic, filamentous, photosynthetic bacterium that lacks chlorosomes. Int J Syst Evol Microbiol 52, 187-193.

Hasegawa, M., Kishino, H. \& Yano, T. A. (1985). Dating of the human-ape splitting by a molecular clock of mitochondrial DNA. J Mol Evol 22, 160-174.

Hattori, S., Kamagata, Y., Hanada, S. \& Shoun, H. (2000). Thermacetogenium phaeum gen. nov., sp. nov., a strictly anaerobic, thermophilic, syntrophic acetate-oxidizing bacterium. Int J Syst Evol Microbiol 50, 1601-1609.

Heising, S., Richter, L., Ludwig, W. \& Schink, B. (1999). Chlorobium ferrooxidans sp. nov., a phototrophic green sulfur bacterium that oxidizes ferrous iron in coculture with a "Geospirillum" sp. strain. Arch Microbiol 172, 116-124.

Hewitt, E. J. \& Nicholas, D. J. D. (1964). Enzymes of inorganic nitrogen metabolism. In Modern Methods of Plant Analysis, pp. 167172. Edited by H. F. Linskens, B. D. Sanwal \& M. V. Tracey. Berlin: Springer.

Hirayama, H., Sunamura, M., Takai, K., Nunoura, T., Noguchi, T., Oida, H., Furushima, Y., Yamamoto, H., Oomori, T. \& Horikoshi, K. (2007). Culture-dependent and -independent characterization of microbial communities associated with a shallow submarine hydrothermal system occurring within a coral reef off Taketomi Island, Japan. Appl Environ Microbiol 73, 7642-7656.

Imhoff, J. F. (2005a). Family I. Chromatiaceae Bavendamm 1924, 125AL emend. Imhoff 1984b, 339. In Bergey's Manual of Systematic Bacteriology, 2nd edn, vol. 2B, pp. 3-9. Edited by D. J. Brenner, N. R. Krieg \& J. T. Staley. New York: Springer.

Imhoff, J. F. (2005b). Family I. Ectothiorhodospiraceae Imhoff 1984b, 339VP. In Bergey's Manual of Systematic Bacteriology, 2nd edn, vol. 2B, pp. 41-43. Edited by D. J. Brenner, N. R. Krieg \& J. T. Staley. New York: Springer.

Inagaki, F., Tsunogai, U., Suzuki, M., Kosaka, A., Machiyama, H., Takai, K., Nunoura, T., Nealson, K. H. \& Horikoshi, K. (2004). Characterization of $\mathrm{C} 1$-metabolizing prokaryotic communities in methane seep habitats at the Kuroshima Knoll, southern Ryukyu Arc, by analyzing $p m o A, m m o X, m x a F, m c r A$, and $16 \mathrm{~S}$ rRNA genes. Appl Environ Microbiol 70, 7445-7455. 
Ito, T., Sugita, K., Yumoto, I., Nodasaka, Y. \& Okabe, S. (2005). Thiovirga sulfuroxydans gen. nov., sp. nov., a chemolithoautotrophic sulfur-oxidizing bacterium isolated from a microaerobic waste-water biofilm. Int J Syst Evol Microbiol 55, 1059-1064.

Li, L., Kato, C. \& Horikoshi, K. (1999). Microbial diversity in sediments collected from the deepest cold-seep area, the Japan Trench. Mar Biotechnol (NY) 1, 391-400.

Ludwig, W., Strunk, O., Westram, R., Richter, L., Meier, H., Yadhukumar, Buchner, A., Lai, T., Steppi, S. \& other authors (2004). ARB: a software environment for sequence data. Nucleic Acids Res 32, 1363-1371.

Marteinsson, V. T., Birrien, J. L., Kristjánsson, J. K. \& Prieur, D. (1995). First isolation of thermophilic aerobic non-sporulating heterotrophic bacteria from deep-sea hydrothermal vents. FEMS Microbiol Ecol 18, 163-174.

Meyer, B., Imhoff, J. F. \& Kuever, J. (2007). Molecular analysis of the distribution and phylogeny of the soxB gene among sulfur-oxidizing bacteria - evolution of the Sox sulfur oxidation enzyme system. Environ Microbiol 9, 2957-2977.

Mori, K. \& Suzuki, K.-i. (2008). Thiofaba tepidiphila gen. nov., sp. nov., a novel obligately chemolithoautotrophic, sulfur-oxidizing bacterium of the Gammaproteobacteria isolated from a hot spring. Int J Syst Evol Microbiol 58, 1885-1891.

Mori, K., Yamamoto, H., Kamagata, Y., Hatsu, M. \& Takamizawa, K. (2000). Methanocalculus pumilus sp. nov., a heavy-metal-tolerant methanogen isolated from a waste-disposal site. Int J Syst Evol Microbiol 50, 1723-1729.

Mori, K., Kim, H., Kakegawa, T. \& Hanada, S. (2003). A novel lineage of sulfate-reducing microorganisms: Thermodesulfobiaceae fam. nov., Thermodesulfobium narugense, gen. nov., sp. nov., a new thermophilic isolate from a hot spring. Extremophiles 7, 283-290.

Mori, K., Maruyama, A., Urabe, T., Suzuki, K.-i. \& Hanada, S. (2008). Archaeoglobus infectus sp. nov., a novel thermophilic, chemolithoheterotrophic archaeon isolated from a deep-sea rock collected at Suiyo Seamount, Izu-Bonin Arc, western Pacific Ocean. Int J Syst Evol Microbiol 58, 810-816.

Nakagawa, Y. \& Yamasato, K. (1993). Phylogenetic diversity of the genus Cytophaga revealed by $16 \mathrm{~S}$ rRNA sequencing and menaquinone analysis. J Gen Microbiol 139, 1155-1161.

NBRC (2010). NBRC Catalogue of Biological Resources: Microorganisms, Microorganism-Related DNA Resources, and Human-Related DNA Resources. 2nd edn. Chiba, Japan: National Institute of Technology and Evaluation (NITE).

Saitou, N. \& Nei, M. (1987). The neighbor-joining method: a new method for reconstructing phylogenetic trees. Mol Biol Evol 4, 406-425.

Santelli, C. M., Orcutt, B. N., Banning, E., Bach, W., Moyer, C. L., Sogin, M. L., Staudigel, H. \& Edwards, K. J. (2008). Abundance and diversity of microbial life in ocean crust. Nature 453, 653-656.
Sievert, S. M., Heidorn, T. \& Kuever, J. (2000). Halothiobacillus kellyi sp. nov., a mesophilic, obligately chemolithoautotrophic, sulfuroxidizing bacterium isolated from a shallow-water hydrothermal vent in the Aegean Sea, and emended description of the genus Halothiobacillus. Int J Syst Evol Microbiol 50, 1229-1237.

Sorokin, D. Y., Tourova, T. P., Kolganova, T. V., Sjollema, K. A. \& Kuenen, J. G. (2002). Thioalkalispira microaerophila gen. nov., sp. nov., a novel lithoautotrophic, sulfur-oxidizing bacterium from a soda lake. Int J Syst Evol Microbiol 52, 2175-2182.

Sorokin, D. Y., Tourova, T. P., Bezsoudnova, E. Y., Pol, A. \& Muyzer, G. (2007). Denitrification in a binary culture and thiocyanate metabolism in Thiohalophilus thiocyanoxidans gen. nov. sp. nov. - a moderately halophilic chemolithoautotrophic sulfur-oxidizing Gammaproteobacterium from hypersaline lakes. Arch Microbiol 187, 441-450.

Sunamura, M., Higashi, Y., Miyako, C., Ishibashi, J. \& Maruyama, A. (2004). Two bacteria phylotypes are predominant in the Suiyo seamount hydrothermal plume. Appl Environ Microbiol 70, 11901198.

Takai, K. \& Horikoshi, K. (1999). Genetic diversity of archaea in deepsea hydrothermal vent environments. Genetics 152, 1285-1297.

Takai, K., Komatsu, T., Inagaki, F. \& Horikoshi, K. (2001). Distribution of archaea in a black smoker chimney structure. Appl Environ Microbiol 67, 3618-3629.

Takai, K., Inagaki, F., Nakagawa, S., Hirayama, H., Nunoura, T., Sako, Y., Nealson, K. H. \& Horikoshi, K. (2003). Isolation and phylogenetic diversity of members of previously uncultivated $\varepsilon$-Proteobacteria in deep-sea hydrothermal fields. FEMS Microbiol Lett 218, 167174.

Takai, K., Hirayama, H., Nakagawa, T., Suzuki, Y., Nealson, K. H. \& Horikoshi, K. (2004). Thiomicrospira thermophila sp. nov., a novel microaerobic, thermotolerant, sulfur-oxidizing chemolithomixotroph isolated from a deep-sea hydrothermal fumarole in the TOTO caldera, Mariana Arc, Western Pacific. Int J Syst Evol Microbiol 54, 2325-2333.

Takai, K., Miyazaki, M., Hirayama, H., Nakagawa, S., Querellou, J. \& Godfroy, A. (2009). Isolation and physiological characterization of two novel, piezophilic, thermophilic chemolithoautotrophs from a deep-sea hydrothermal vent chimney. Environ Microbiol 11, 1983 1997.

Tamaki, H., Hanada, S., Kamagata, Y., Nakamura, K., Nomura, N., Nakano, K. \& Matsumura, M. (2003). Flavobacterium limicola sp. nov., a psychrophilic, organic-polymer-degrading bacterium isolated from freshwater sediments. Int J Syst Evol Microbiol 53, 519526.

Thompson, J. D., Gibson, T. J., Plewniak, F., Jeanmougin, F. \& Higgins, D. G. (1997). The CLUSTAL_X windows interface: flexible strategies for multiple sequence alignment aided by quality analysis tools. Nucleic Acids Res 25, 4876-4882. 